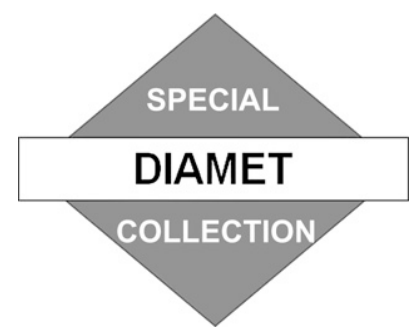

\title{
Using Frontogenesis to Identify Sting Jets in Extratropical Cyclones
}

\author{
DAVID M. SCHULTZ \\ Centre for Atmospheric Science, School of Earth, Atmospheric and Environmental Sciences, University of Manchester, \\ Manchester, United Kingdom \\ JOSEPH M. SIENKIEWICZ \\ NOAA/NWS/NCEP/Ocean Prediction Center, College Park, Maryland
}

(Manuscript received 5 December 2012, in final form 13 March 2013)

\begin{abstract}
Sting jets, or surface wind maxima at the end of bent-back fronts in Shapiro-Keyser cyclones, are one cause of strong winds in extratropical cyclones. Although previous studies identified the release of conditional symmetric instability as a cause of sting jets, the mechanism to initiate its release remains unidentified. To identify this mechanism, a case study was selected of an intense cyclone over the North Atlantic Ocean during 7-8 December 2005 that possessed a sting jet detected from the NASA Quick Scatterometer (QuikSCAT). A couplet of Petterssen frontogenesis and frontolysis occurred along the bent-back front. The direct circulation associated with the frontogenesis led to ascent within the cyclonically turning portion of the warm conveyor belt, contributing to the comma-cloud head. When the bent-back front became frontolytic, an indirect circulation associated with the frontolysis, in conjunction with alongfront cold advection, led to descent within and on the warm side of the front, bringing higher-momentum air down toward the boundary layer. Sensible heat fluxes from the ocean surface and cold-air advection destabilized the boundary layer, resulting in near-neutral static stability facilitating downward mixing. Thus, descent associated with the frontolysis reaching a near-neutral boundary layer provides a physical mechanism for sting jets, is consistent with previous studies, and synthesizes existing knowledge. Specifically, this couplet of frontogenesis and frontolysis could explain why sting jets occur at the end of the bent-back front and emerge from the cloud head, why sting jets are mesoscale phenomena, and why they only occur within Shapiro-Keyser cyclones. A larger dataset of cases is necessary to test this hypothesis.
\end{abstract}

\section{Introduction}

Extreme winds in extratropical cyclones often occur south of the surface low center (e.g., Lynott and Cramer 1966; Neiman et al. 1993; Grønås 1995; Steenburgh and Mass 1996; Nielsen and Sass 2003; Von Ahn et al. 2006; Chelton et al. 2006; Knox et al. 2011; Fox et al. 2012; Hanafin et al. 2012). Studying the United Kingdom's Great Storm of 15-16 October 1987, Browning (2004) coined the term sting jet to refer to one specific type of wind maximum in this region. The term refers to

Corresponding author address: Prof. David M. Schultz, Centre for Atmospheric Science, School of Earth, Atmospheric and Environmental Sciences, University of Manchester, Simon Building, Oxford Road, Manchester M13 9PL, United Kingdom.

E-mail: david.schultz@manchester.ac.uk
Grønås's (1995) invocation of the "poisonous tail of the bent-back occlusion," deriving from the Norwegian School's recognition of strong winds at the end of a bentback occluded front in many cyclones that are now known as Shapiro-Keyser (1990) cyclones.

Wind speed maxima resembling sting jets have been identified in other North Atlantic, North Pacific, and European cyclones (e.g., Von Ahn et al. 2005; Parton et al. 2010; Baker et al. 2013b). Martínez-Alvarado et al. (2012) found that almost a third of the 100 most intense windstorms over the North Atlantic Ocean during winter months from December 1989 to February 2009 may have had precursor conditions that led to sting jets. Although landfalling cyclones in the Pacific Northwest may have similar surface wind maxima, Mass and Dotson (2010) found no evidence that these maxima were associated with sting jets. 
Besides sting jets, strong winds in cyclones may also occur in association with the cold conveyor belt. The cold conveyor belt is a near-surface airstream of cold air underneath the warm-frontal zone (Carlson 1980; Schultz 2001). Strong winds in cold conveyor belts may or may not be present in addition to sting jets (e.g., Clark et al. 2005; Baker 2009; Gray et al. 2011; Baker et al. 2013a; Smart and Browning 2013). The physical processes that lead to strong winds in the sting jet versus those that lead to strong winds in the cold conveyor belt have not been elucidated. As an initial contribution to this topic, this article focuses on the sting jet and the physical processes leading to the strong winds at the surface.

Two physical processes have been proposed to account for strong winds in cyclones with sting jets: subcloud evaporative cooling and conditional symmetric instability. First, Browning (2004) proposed that evaporation and sublimation of hydrometeors from the head of the comma cloud might increase the magnitude of the surface winds. Fox et al. (2012, p. 270) described this process as "a result of snow evaporating rapidly, which in turn quickly cools the surrounding air. This cooler, denser air then descends, transferring momentum to the ground." However, mesoscale modeling studies of both real cyclones and idealized baroclinic waves in which evaporative cooling is turned off do not yield stronger surface winds (T. Baker and P. Knippertz 2012, personal communication; Baker et al. 2013a; Smart and Browning 2013). Although evaporation may be occurring within the subcloud air that becomes the sting jet, evaporation may not be crucial to the formation of strong winds.

Second, Browning (2004) argued that banding in the cloud head caused by multiple slantwise circulation patterns was associated with the release of conditional symmetric instability (CSI; Bennetts and Hoskins 1979; reviewed in Schultz and Schumacher 1999). CSI has also been identified in other sting-jet cases (e.g., Parton et al. 2009; Gray et al. 2011; Martínez-Alvarado et al. 2011; Baker et al. 2013a) and idealized baroclinic waves (Cao 2009). [Baker et al. (2013a) argued that the 50-km horizontal grid spacing and 14 vertical levels was inadequate to produce a sting jet in Cao (2009).] Diagnostic tools have been developed that employ measures of CSI for finding sting jets in a large number of cases (e.g., Baker 2009; Gray et al. 2011; Martínez-Alvarado et al. 2011, 2012). As a consequence of these eight studies listed above, Baker et al. (2013a) stated that, "instability release is the dominant sting-jet driving mechanism," and the release of CSI has become the leading physical mechanism proposed to explain the intensity of winds in sting jets.

The release of CSI as the cause of sting jets, however, is problematic. As discussed in section 2 of Schultz and Schumacher (1999), CSI cannot "cause" slantwise convection or sting jets (e.g., Parton et al. 2009, p. 678): CSI depends upon sufficient vertical motion to initiate its release. Yet, articles on sting jets to date have not identified the source of that vertical motion. To draw an analogy, it would be as if the presence of conditional instability alone were invoked to explain the formation of a squall line, without consideration of the lifting mechanism to initiate the convection.

This article presents a case study of an intense extratropical cyclone with an observed sting jet over the North Atlantic Ocean and proposes a simple diagnostic approach using Petterssen (1936) frontogenesis that identifies the region in a cyclone with the potential to develop strong winds due to a sting jet. Also, this article demonstrates the physical mechanism responsible for the sting jet in this case.

\section{Petterssen frontogenesis}

Petterssen (1936) frontogenesis $F$ is the time rate of change of the magnitude of the horizontal gradient of potential temperature $\theta$ following the flow:

$$
F=\frac{d}{d t}\left|\nabla_{H} \theta\right|
$$

where

$$
\begin{aligned}
\frac{d}{d t} & =\frac{\partial}{\partial t}+u \frac{\partial}{\partial x}+v \frac{\partial}{\partial y}, \\
\mathbf{V}_{H} & =u \mathbf{i}+v \mathbf{j}, \\
\nabla_{H} & =\mathbf{i} \frac{\partial}{\partial x}+\mathbf{j} \frac{\partial}{\partial y} .
\end{aligned}
$$

Petterssen (1936) showed that this expression for $F$ could be written in terms of deformation and divergence:

$$
F=\frac{1}{2}\left|\nabla_{H} \theta\right|\left(E \cos 2 \beta-\nabla_{H} \cdot \mathbf{V}_{H}\right),
$$

where $E$ is the resultant deformation and $\beta$ is the local angle between an isentrope and the axis of dilatation. Positive regions of frontogenesis indicate where isentropes are instantaneously being brought together by the horizontal flow, thereby increasing the horizontal potential temperature gradient. Negative regions of frontogenesis (or frontolysis) indicate where isentropes are instantaneously being spread apart by the horizontal flow, thereby weakening the horizontal potential temperature gradient.

Frontogenesis is associated with a direct circulation with rising warm air and sinking cold air on either side of the maximum of frontogenesis (e.g., Eliassen 1962; 


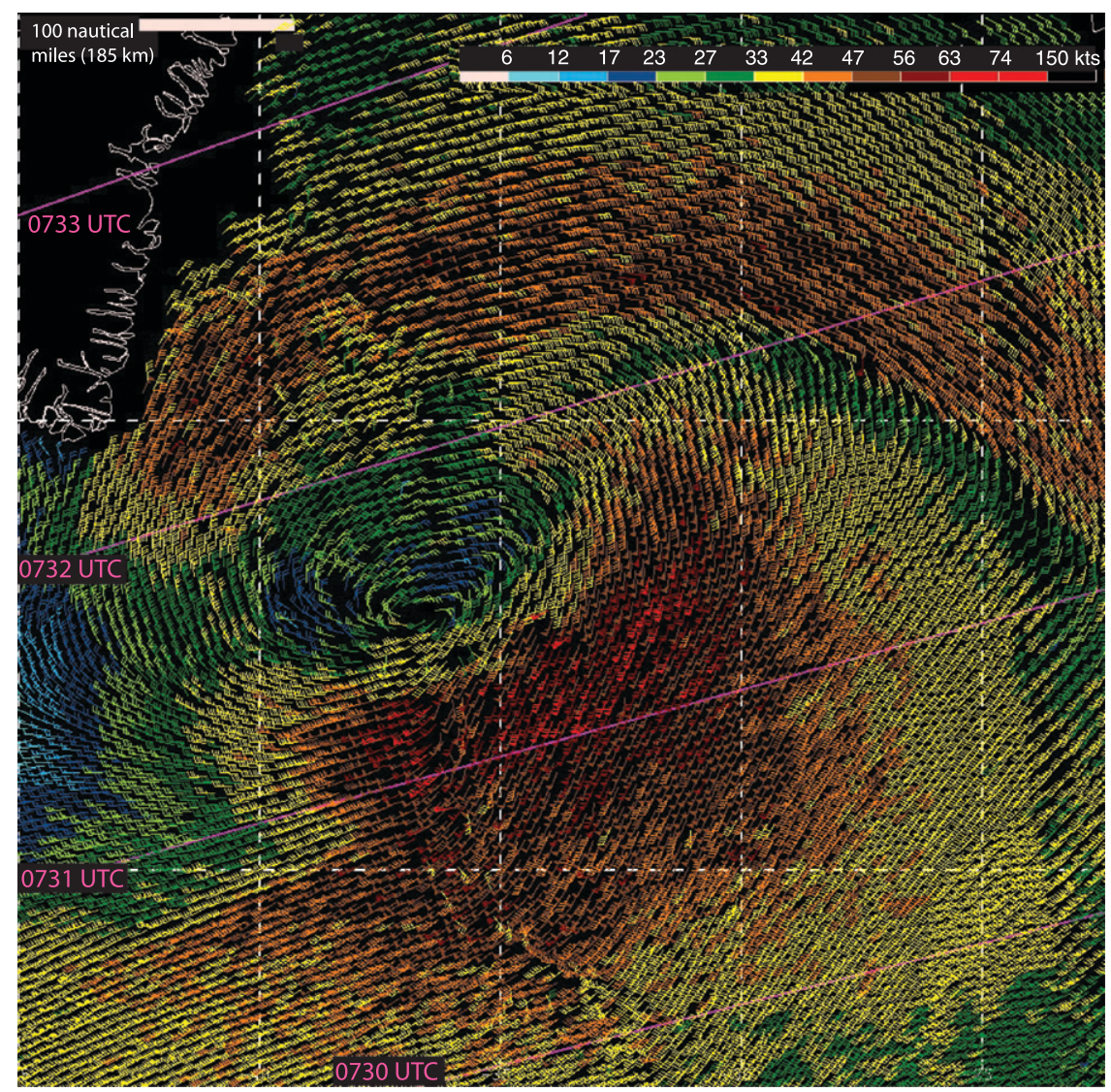

FIG. 1. QuikSCAT imagery of horizontal wind speed and direction at 0730-0733 UTC 8 Dec 2005 (pennant, full barb, and half-barb denote 50, 10, and $5 \mathrm{kt}$, respectively, where $1 \mathrm{kt}=0.514 \mathrm{~m} \mathrm{~s}^{-1}$; separation between displayed wind vectors is $12.5 \mathrm{~km}$ ). The colored wind barbs represent wind speed (kt) according to the scale in the top-right corner, the pink lines represent satellite overpass times, and the scale bar in the top-left corner represents 100 nautical miles ( $\mathrm{n} \mathrm{mi}$, or $185 \mathrm{~km}$ ).

Keyser et al. 1988). In the presence of cold advection, however, the direct circulation shifts to the warm side of the front so that descent occurs within the region of frontogenesis (Keyser and Pecnick 1985). In contrast, frontolysis is associated with an indirect circulation with sinking warm air and rising cold air. In the presence of cold advection, the indirect circulation shifts so that descent occurs within the region of frontolysis.

Petterssen frontogenesis has been used previously to diagnose fronts in the central United States (e.g., Koch 1984; Keshishian et al. 1994; Martin 1998a; Schultz 2004), the western United States (Steenburgh and Mass 1994; Schultz and Knox 2007; Steenburgh et al. 2009; Schumacher et al. 2010; West and Steenburgh 2010), and idealized baroclinic waves (Schär and Wernli 1993; Schultz and Zhang 2007); to calculate climatologies of frontogenesis (Satyamurty and De Mattos 1989); to determine regions of ascent associated with precipitation bands within heavy rainstorms (Sanders 2000) and within snowstorms (e.g., Bosart and Lin 1984; Keshishian and
Bosart 1987; Roebber et al. 1994; Martin 1998b; Trapp et al. 2001; Novak et al. 2004, 2006, 2008, 2009, 2010); to determine the time of extratropical transition of a tropical cyclone (Harr and Elsberry 2000); and to indicate regions of predecessor precipitation ahead of tropical cyclones (e.g., Galarneau et al. 2010; Moore et al. 2013). Lackmann (2011, sections 6.2 and 6.3) provides a moredetailed description of Petterssen frontogenesis. To date, studies have focused on the regions of frontogenesis as important dynamical features; fewer studies have focused on frontolysis.

\section{North Atlantic Ocean cyclone: 7-8 December 2005}

On 7-8 December 2005, an extratropical cyclone deepened rapidly east of Canada. Based on the operational experience at the Ocean Prediction Center, the case was typical of extratropical cyclones with strong surface winds caused by sting jets. An area of storm-force to 
hurricane-force sustained winds (50-64 kt, $26-33 \mathrm{~m} \mathrm{~s}^{-1}$ ) occurred within about $460 \mathrm{~km}$ to the east and south from the cyclone center at 0731 UTC 8 December, with a

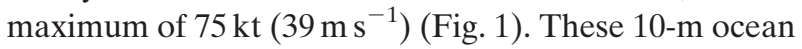
vector winds were derived from the National Aeronautics and Space Administration (NASA) SeaWinds microwave scatterometer on the research Quick Scatterometer polarorbiting satellite (QuikSCAT; e.g., Hoffman and Leidner 2005). QuikSCAT was successfully used by marine forecasters to determine extratropical cyclone intensity and wind warning categories for over 10 years from 1999 through November 2009 (e.g., Von Ahn et al. 2005, 2006; Chelton et al. 2006).

To diagnose the origin of these strong winds in the lower troposphere, an Advanced Research Weather Research and Forecasting Model (WRF-ARW; Skamarock et al. 2005) simulation starting at 1200 UTC 7 December was performed. The model simulation had $12-\mathrm{km}$ horizontal grid spacing. The National Centers for Environmental Prediction (NCEP) Global Forecast System (GFS) was used for the initial and lateral boundary conditions. The following physical parameterizations were implemented: the Yonsei University boundary layer scheme (Hong et al. 2006), the Kain-Fritsch convective parameterization (Kain and Fritsch 1990, 1993; Kain 2004), the Noah land surface model (Chen and Dudhia 2001), the Rapid Radiative Transfer Model for shortand longwave radiation (Mlawer et al. 1997), and Lin et al.'s microphysics (Lin et al. 1983; Rutledge and Hobbs 1984; Tao et al. 1989; Chen and Sun 2002). No data assimilation or nudging was used. Although the winds associated with the sting jet occur specifically at the surface, wind speeds in this article are plotted at $925 \mathrm{hPa}$ because frontal structures are better defined at this level and other sting-jet studies have shown that models have difficulty mixing momentum into the planetary boundary layer (e.g., Parton et al. 2009; Smart and Browning 2013). In this case, the $10-\mathrm{m}$ model winds are about $10-15 \mathrm{~m} \mathrm{~s}^{-1}$ weaker than the $925-\mathrm{hPa}$ winds, and the QuikSCAT winds in Fig. 1 are closer to the $925-\mathrm{hPa}$ model winds at the time of the overpass (not shown).

At 1200 UTC 7 December (Figs. 2a,b), 925-hPa winds exceeded $35 \mathrm{~m} \mathrm{~s}^{-1}$ in the warm sector with a secondary maximum of more than $30 \mathrm{~m} \mathrm{~s}^{-1}$ parallel to and extending along the maximum in negative frontogenesis (frontolysis) along the bent-back front. By 1800 UTC, the cyclone deepened $14 \mathrm{hPa}$, the main region of strong winds in the warm sector moved northeastward, and the bent-back front wrapped equatorward around the cyclone (Fig. 2c). The region of maximum wind speed along the frontolysis increased to over $35 \mathrm{~m} \mathrm{~s}^{-1}$, producing a well-developed sting jet (Fig. 2d). This narrow region of strong winds occurred within the larger region of strong winds surrounding the cyclone, as well as at and downstream of the strongest horizontal pressure gradient (Fig. 2c). The shape of the sting jet at the surface expanded downstream, parallel to and along the frontolysis (Fig. 2d).

The sting jet formed within a large region south of the low center characterized by near-neutral static stability in the boundary layer (Fig. 3a). In this particular case, this well-mixed boundary layer occurred because of both strong cold advection (Fig. 3b) and strong surface sensible heat flux (Fig. 3c). Indeed, this sensible heat flux exceeding $400 \mathrm{~W} \mathrm{~m}^{-2}$ is comparable in magnitude to the sensible heat fluxes of other rapidly developing marine cyclones from observations (e.g., Neiman et al. 1990; Crescenti and Weller 1992) and model simulations (e.g., Chang et al. 1996; Gozzo and da Rocha 2013).

At 0000 UTC 8 December, the cyclone deepened to $953 \mathrm{hPa}$, and the maximum wind speed increased to over $40 \mathrm{~m} \mathrm{~s}^{-1}$ (Fig. 2e). The region of frontolysis along the bent-back front shrank to a sliver, which is where the strongest winds were occurring (Fig. 2f).

To illustrate further the close association between the frontolysis and the strong winds, cross sections were taken across the region of frontogenesis along the occluded front northeast of the low center $\left(\mathrm{AA}^{\prime}\right)$ and across the region of frontolysis along the bent-back front south of the low center $\left(\mathrm{BB}^{\prime}\right)$ at 1800 UTC 7 December (Fig. 4; cross-section locations shown in Fig. 2). In $\mathrm{AA}^{\prime}$, the wind speed was a maximum in two locations (Fig. 4a): in the warm conveyor belt in the warm sector (labeled WCB into the page) and in the cyclonically turning portion of the warm conveyor belt in the midtroposphere (labeled WCB out of the page). The warm air rose above the bent-back frontal zone, with ascent exceeding $-3.6 \mathrm{~Pa} \mathrm{~s}^{-1}$ within and on the warm side of the region of frontogenesis (Fig. 4b). In contrast to this direct circulation across the region of frontogenesis, an indirect circulation pattern existed across the region of frontolysis $\left(\mathrm{BB}^{\prime}\right)$ with descent of $1.2 \mathrm{~Pa} \mathrm{~s}^{-1}$ within and on the warm side of the frontolysis (Figs. 4c,d). Thus, in addition to any strengthening of the cyclone-scale winds associated with the intensifying cyclone (Fig. 2), mesoscale descent along and within the frontal zone facilitated the descent of higher-momentum air from aloft down to the surface.

This transition from ascent to descent, and its relationship to the head of the comma cloud, is illustrated by the $700-\mathrm{hPa}$ relative humidity field (Figs. 5a,b). At both 1800 UTC 7 December and 0000 UTC 8 December, the strongest winds associated with the sting jet were adjacent to and below the near-saturated area in the model, displaying a relationship consistent with previous studies (Browning 2004; Clark et al. 2005; Parton et al. 2009; Baker 2009; Gray et al. 2011). 

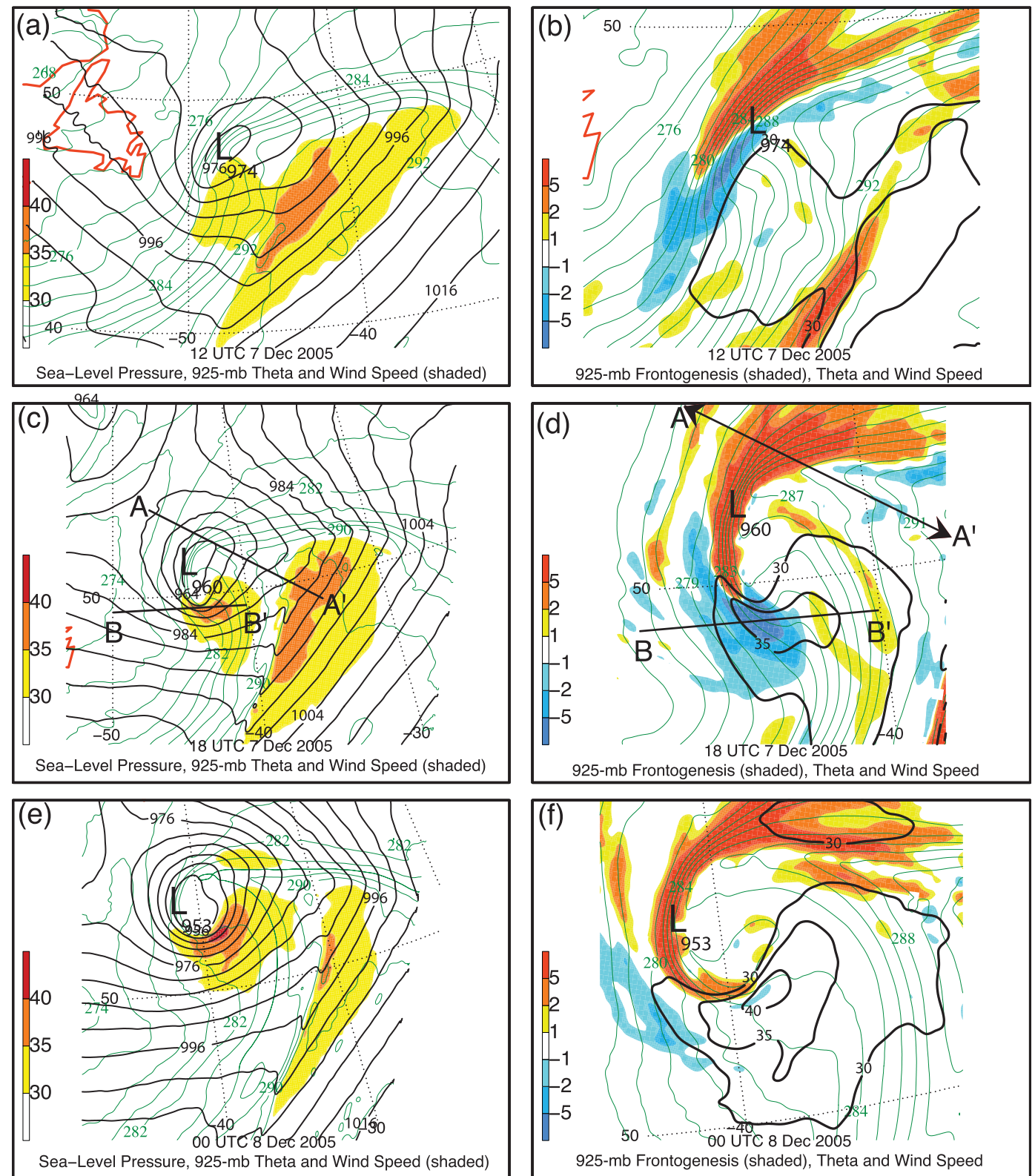

FIG. 2. (a),(c),(e) Sea level pressure (thick solid lines every $4 \mathrm{hPa}$ ), 925-hPa potential temperature (green lines every $2 \mathrm{~K}$ ), and $925-\mathrm{hPa}$ wind speed ( $\mathrm{m} \mathrm{s}^{-1}$, shaded according to scale at the left side of the panel). (b),(d),(f) Zoomed-in view of 925-hPa Petterssen frontogenesis [K $(100 \mathrm{~km})^{-1}(3 \mathrm{~h})^{-1}$, shaded according to scale at the left side of the panel], 925-hPa potential temperature (green lines every $1 \mathrm{~K}$ ), $925-\mathrm{hPa}$ wind speed (thick solid lines every $5 \mathrm{~m} \mathrm{~s}^{-1}$ starting at $30 \mathrm{~m} \mathrm{~s}^{-1}$ ), and location of sea level pressure minimum denoted by L. Solid lines in (c) and (d) represent locations of cross sections in Fig. 4. Results shown are for (a),(b) 12 UTC 7 Dec, (c), (d) 1800 UTC 7 Dec, and (e),(f) 0000 UTC 8 Dec 2005. All fields are derived from a WRF simulation initialized at 1200 UTC 7 Dec 2005 and passed through the 9-point smoother within the General Meteorology Package (GEMPAK; desJardins et al. 1991).

\section{Synthesis}

The results of this case study support a new hypothesis accounting for the physical mechanism of the sting jet. As the saturated flow in the cyclonic portion of the warm conveyor belt travels around the cyclone center along the bent-back front, the transition from frontogenesis to frontolysis is crucial to the formation of a possible sting jet (Fig. 6). The reversal of the vertical circulation from ascent to descent on the warm side of the front, coupled with the strengthening winds associated with the intensifying cyclone, brings high-momentum air down 

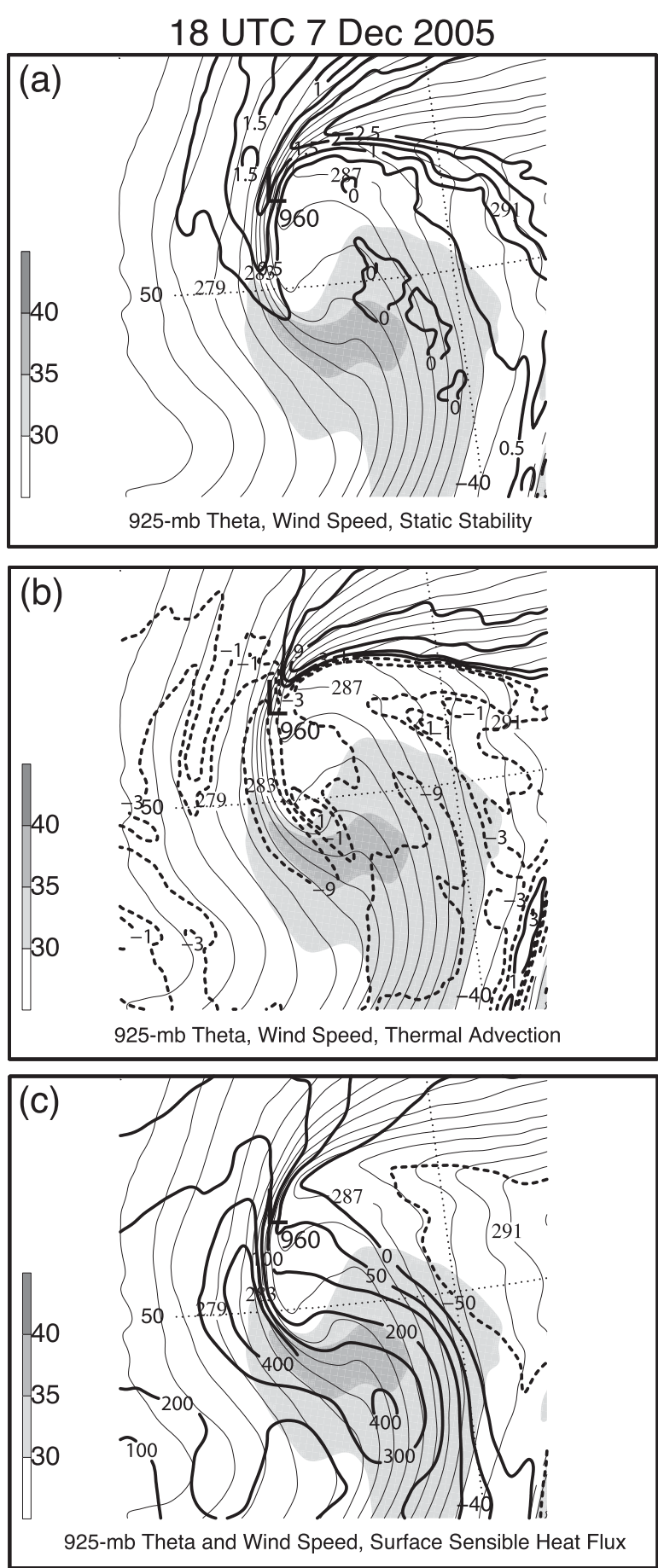

FIG. 3. The 925-hPa potential temperature (thin solid lines every $1 \mathrm{~K})$ and $925-\mathrm{hPa}$ wind speed $\left(\mathrm{m} \mathrm{s}^{-1}\right.$, shaded according to scale at the left side of the panel) at 1800 UTC 7 Dec 2005. (a) Near-surface static stability measured by the potential temperature at $900 \mathrm{hPa}$ minus the potential temperature at $950 \mathrm{hPa}$ (contoured at -1 , $-0.5,0,0.5,1,1.5,2$, and $2.5 \mathrm{~K}$ ), (b) 925 -hPa potential temperature advection (contoured $-9,-3,-1,1,3$, and $9 \times 10^{-4} \mathrm{~K} \mathrm{~m}^{-1} \mathrm{~s}^{-1}$ ), and (c) surface sensible heat flux $\left(\mathrm{W} \mathrm{m}^{-2}\right)$. All fields are derived from a WRF simulation initialized at 1200 UTC 7 Dec 2005 and are passed through the 9-point smoother within GEMPAK. from aloft into the lower troposphere, possibly even to the surface, with the maximum winds in the lower troposphere occurring downstream of the frontolysis (Fig. 6). Given a favorable near-surface environment of nearneutral static stability (a result of the cold advection and sensible heat fluxes), strong winds can reach the surface as a localized wind maximum (the sting jet). Thus, ironically, the rapid weakening of the bent-back front is responsible for the strongest winds at the surface.

This new hypothesis explains three critical observations about sting jets.

\section{a. Why sting jets occur at the end of the bent-back front and edge of the cloud head}

The frontolysis at the end of the bent-back front is where the isentropes spread apart in the horizontal. Combined with the lower static stability produced by the cold-air advection and sensible heat fluxes, downward momentum transfer occurs, producing the sting jet. Indeed, no less than six previously published figures have shown that the sting jet occurs downstream of the spreading of the isentropes (e.g., Figs. $3 \mathrm{~b}$ and $4 \mathrm{~b}$ in Grønås 1995; Fig. 7 in Clark et al. 2005; Fig. 5 in Baker 2009; Fig. 12 in Smart and Browning 2013; Fig. 5 in Baker et al. 2013a). These cases provide support for the generality of this approach beyond the single case study presented in this article.

Moreover, the transition between ascent and descent associated with Petterssen frontogenesis is consistent with the transition between ascent and descent along sting-jet trajectories in previous studies (e.g., Clark et al. 2005; Smart and Browning 2013) and explains why the sting jet emerges from the cloud head: the forced descent associated with the frontolysis evaporates the cloud. Although evaporation of precipitation may occur within the sting jet and make the air negatively buoyant, evaporation is not essential to the initiation of the sting jet, and it may not be essential to its intensity, as well (Baker et al. 2013a; Smart and Browning 2013).

\section{b. Why sting jets are mesoscale phenomena}

Because frontogenesis is a mesoscale process and its associated circulation occurs on the mesoscale, the sting jet necessarily will have mesoscale dimensions in the mid- and lower troposphere. For example, Clark et al. (2005) found that the sting jet at $650 \mathrm{hPa}$ was only $50 \mathrm{~km}$ wide. The vertical velocities in sting jets have mesoscale magnitudes of order $1 \mathrm{~Pa} \mathrm{~s}^{-1}$ or $10 \mathrm{~cm} \mathrm{~s}^{-1}$ (Clark et al. 2005; Martínez-Alvarado et al. 2012; Smart and Browning 2013), requiring several hours to realize the descent from the midtroposphere. Indeed, such vertical velocities are sufficient: only $1 \mathrm{~Pa} \mathrm{~s}^{-1}$ of descent acting for $6 \mathrm{~h}$ yields $216 \mathrm{hPa}$ of descent. Moreover, the strongest 

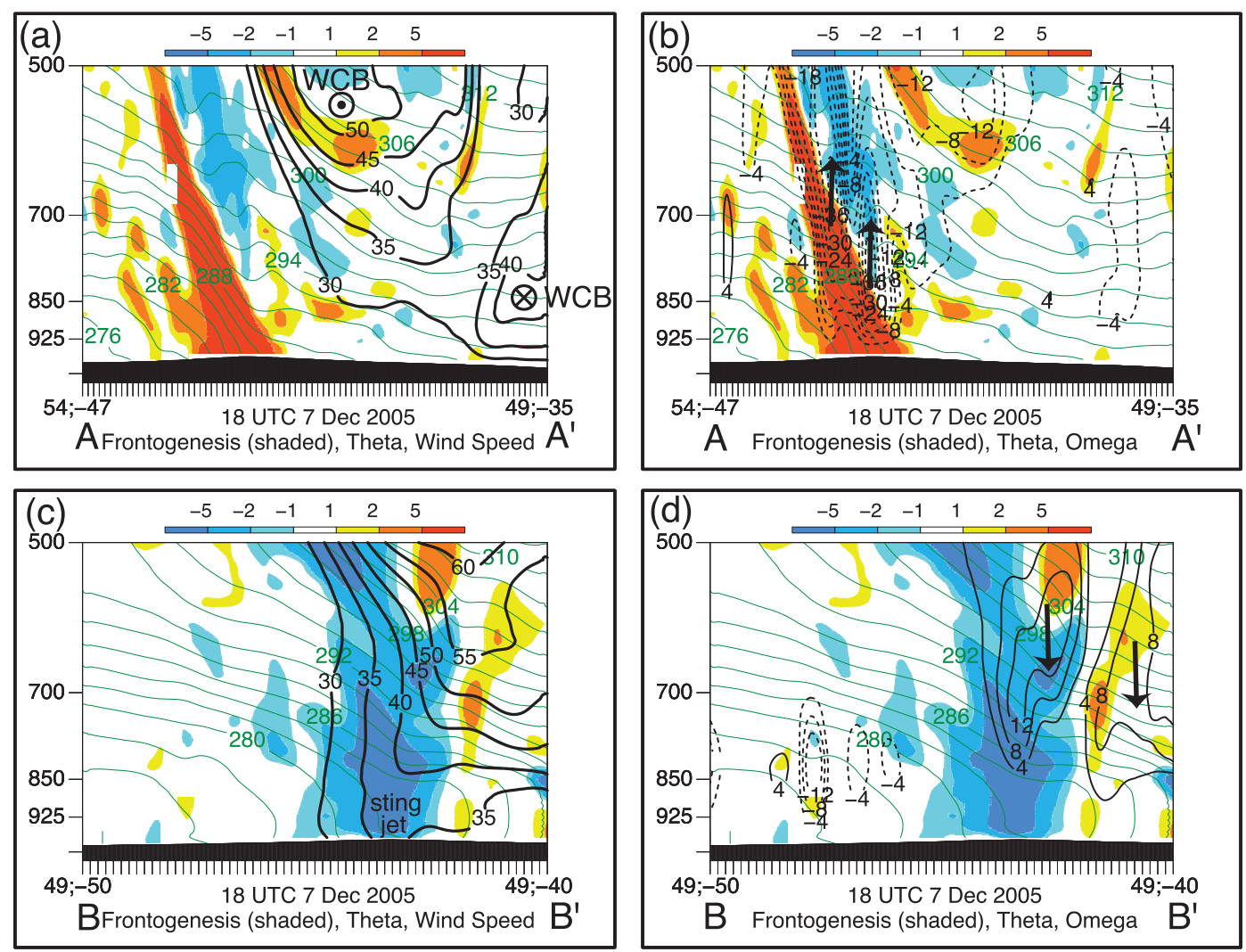

FIG. 4. Vertical cross sections through the bent-back front at 1800 UTC 7 Dec 2005 (locations shown in Fig. 2). Vertical axis is pressure in $\mathrm{hPa}$. Locations are shown where (a),(b) $\mathrm{AA}^{\prime}$ intersects the region of frontogenesis and (c),(d) $\mathrm{BB}^{\prime}$ intersects the region of frontolysis and sting jet. (a),(c) Petterssen frontogenesis $\left[\mathrm{K}(100 \mathrm{~km})^{-1}(3 \mathrm{~h})^{-1}\right.$, shaded according to scale at the top of the panel], potential temperature (green lines every $2 \mathrm{~K}$ ), and wind speed (thick solid lines every $5 \mathrm{~m} \mathrm{~s}^{-1}$ starting at $\left.30 \mathrm{~m} \mathrm{~s}^{-1}\right)$. (b), (d) Petterssen frontogenesis $\left[\mathrm{K}(100 \mathrm{~km})^{-1}(3 \mathrm{~h})^{-1}\right.$, shaded according to scale at the top of the panel], potential temperature (green lines every $2 \mathrm{~K}$ ), and omega (dashed lines and arrows represent ascent labeled at $-0.4,-0.8,-1.2,-1.8,-2.4,-3.0$, and $-3.6 \mathrm{~Pa} \mathrm{~s}^{-1}$; solid lines and arrows denote descent every $0.4 \mathrm{~Pa} \mathrm{~s}^{-1}$ ). The sting jet and the warm conveyor belt (WCB) into $(\otimes)$ and out of $(\odot)$ the page are labeled. Each tick mark on the horizontal axis represents $12 \mathrm{~km}$. All fields are derived from a WRF simulation initialized at 1200 UTC 7 Dec 2005 and are passed through the 9-point smoother within GEMPAK.

winds do not need to be collocated with the strongest descent or the strongest winds in order to produce a localized wind maximum. All that is required is that localized descent occurs in a region where the wind speed increases with height. Trajectories presented in previous studies confirm the midtropospheric origin of the sting jet (e.g., Baker 2009; Parton et al. 2010; Gray et al. 2011; Baker et al. 2013a), which is consistent with the vertical scale of the frontal zone (e.g., Fig. 17 in Neiman et al. 1993; Fig. 13 in Clark et al. 2005; Figs. 16-17 in Parton et al. 2009; Fig. 6d in Smart and Browning 2013). All this evidence points to a mesoscale phenomenon related to the front responsible for the descent.

\section{c. Why sting jets only occur in Shapiro-Keyser cyclones}

Parton et al.'s (2010) climatology of strong-wind events over the United Kingdom indicated that sting jets only occurred within Shapiro-Keyser cyclones. Petterssen frontogenesis indicates why sting jets are favored in Shapiro-Keyser cyclones, but not Norwegian cyclones (Fig. 7). The diffluence at the end of bent-back fronts in Shapiro-Keyser cyclones favors frontolysis and descent on the warm side of the front (Fig. 7b), but no frontolysis happens in the wrap-up characterizing occluded fronts in Norwegian cyclones (Fig. 7a; Rotunno et al. 1998; Schultz and Vaughan 2011). Indeed, calculations of near-surface Petterssen frontogenesis in Shapiro-Keyser cyclones are frontolytic at the end of the bent-back front (e.g., Figs. 11a and 15a in Takayabu 1986; Fig. 13c in Schär and Wernli 1993; Fig. 7 in Schultz et al. 1998; Figs. 4e,f in Schultz and Zhang 2007), but regions of near-surface frontolysis in developing and mature Norwegian cyclones are almost entirely absent (e.g., Fig. 14 in Schultz and Mass 1993; Figs. 4d,h in Market and Moore 1998; Figs. 18a,b in Martin 1998a; Fig. 3 in Schultz et al. 1998). 

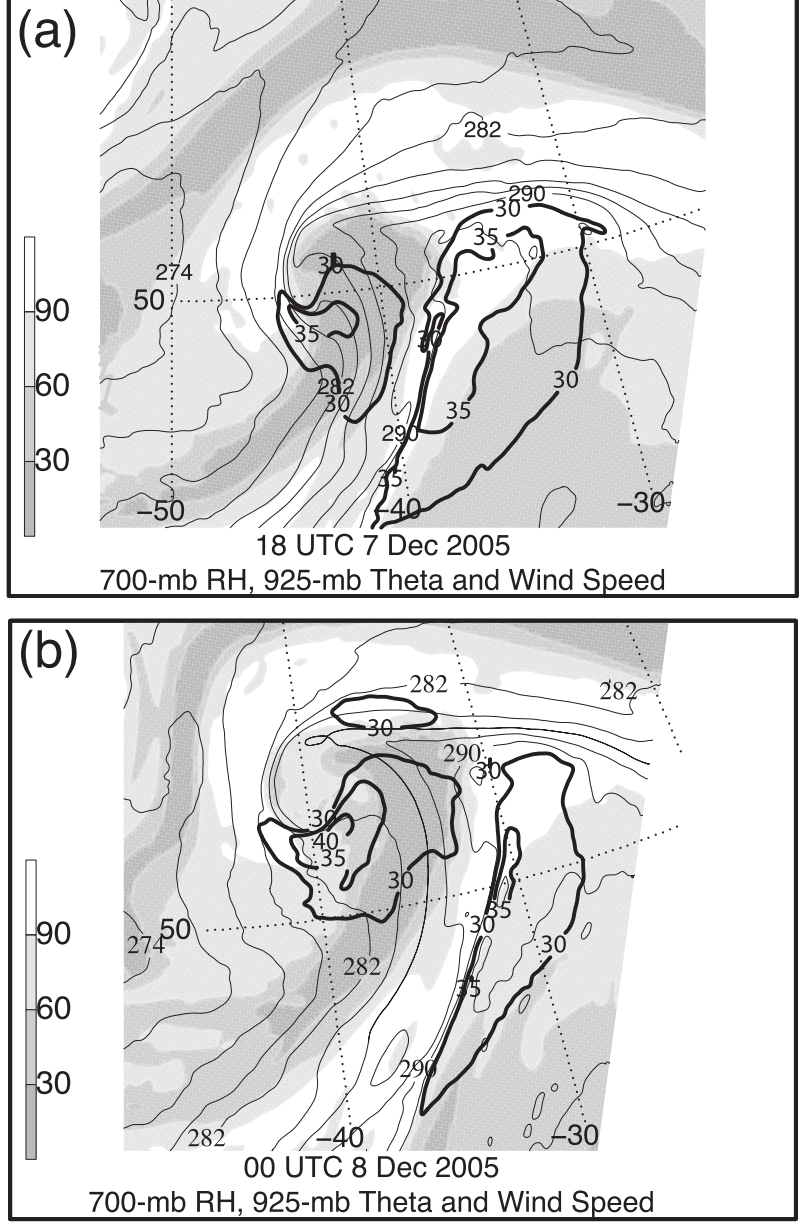

FIG. 5. The 700-hPa relative humidity (\%, shaded according to scale at the left side of the panel), $925-\mathrm{hPa}$ potential temperature (thin solid lines every $2 \mathrm{~K}$ ), and $925-\mathrm{hPa}$ wind speed (thick solid lines every $5 \mathrm{~m} \mathrm{~s}^{-1}$ starting at $30 \mathrm{~m} \mathrm{~s}^{-1}$ ). (a) 1800 UTC 7 Dec and (b) 0000 UTC 8 Dec 2005. All fields are derived from a WRF simulation initialized at 1200 UTC 7 Dec 2005 and are passed through the 9-point smoother within GEMPAK.

This hypothesis is based on previous and present research and motivates the following proposed forecasting approach. Although the sting jet is a maximum of strong surface winds, these winds originate aloft and are advected down by the frontolytical secondary circulation (perhaps with acceleration along the way). For these midtropospheric winds to reach the surface, two conditions must be met.

First, frontolysis and the resulting secondary circulation must be strong enough and last long enough to advect strong winds aloft down to the lower troposphere. Because the intensity of a frontal circulation depends upon the symmetric stability (e.g., Thorpe and Emanuel 1985), even frontal circulations in a symmetrically stable environment may produce descent. CSI may

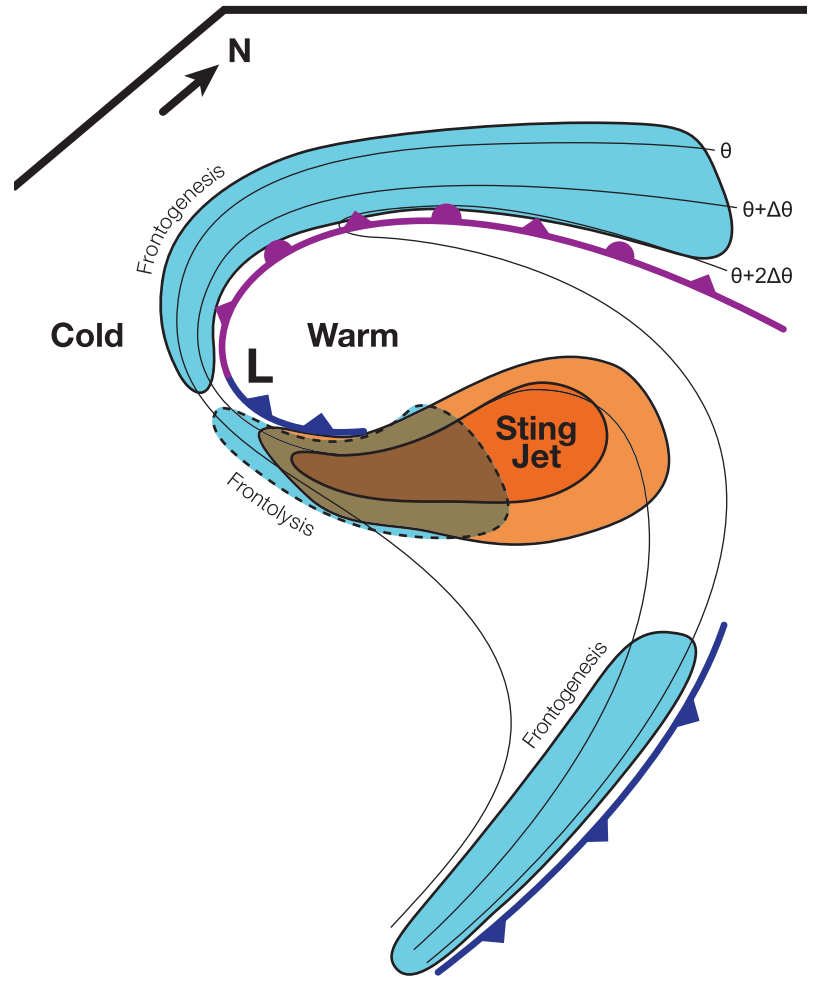

FIG. 6. Conceptual model for the location of a sting jet (orange shading) in a Shapiro-Keyser cyclone, highlighting regions of lowertropospheric frontogenesis (blue shading surrounded by solid lines) and frontolysis (blue shading surrounded by dashed lines). Thin lines are lower-tropospheric (e.g., $925 \mathrm{hPa}$ ) isentropes $(\theta, \theta+\Delta \theta$, $\theta+2 \Delta \theta$ ), frontal symbols are conventional, and $\mathrm{L}$ marks the position of the surface low center.

enhance the frontal circulation, producing more rapid descent and greater accelerations (e.g., Gray et al. 2011; Baker et al. 2013a), and CSI may distinguish those sting jets that reach the surface from those that do not (Gray et al. 2011). Nevertheless, the forcing associated with the frontolysis determines the location of the descent. The stability merely modulates the strength of the descent.

Second, whether the descending air reaches the surface depends upon the static stability of the boundary layer. If the stability is too large, weak vertical mixing may inhibit the downward advection of high-momentum air (e.g., Browning and Field 2004; Baker et al. 2013a). Indeed, our results show that the sting jet occurs in a region of near-neutral static stability near the surface, which would facilitate efficient mixing within the boundary layer.

Although this article argues for the utility of Petterssen frontogenesis to locate potential sting jets, such an approach cannot be used to identify regions of strong winds associated with the cold conveyor belt. As discussed previously, the strong winds in the cold conveyor belt 

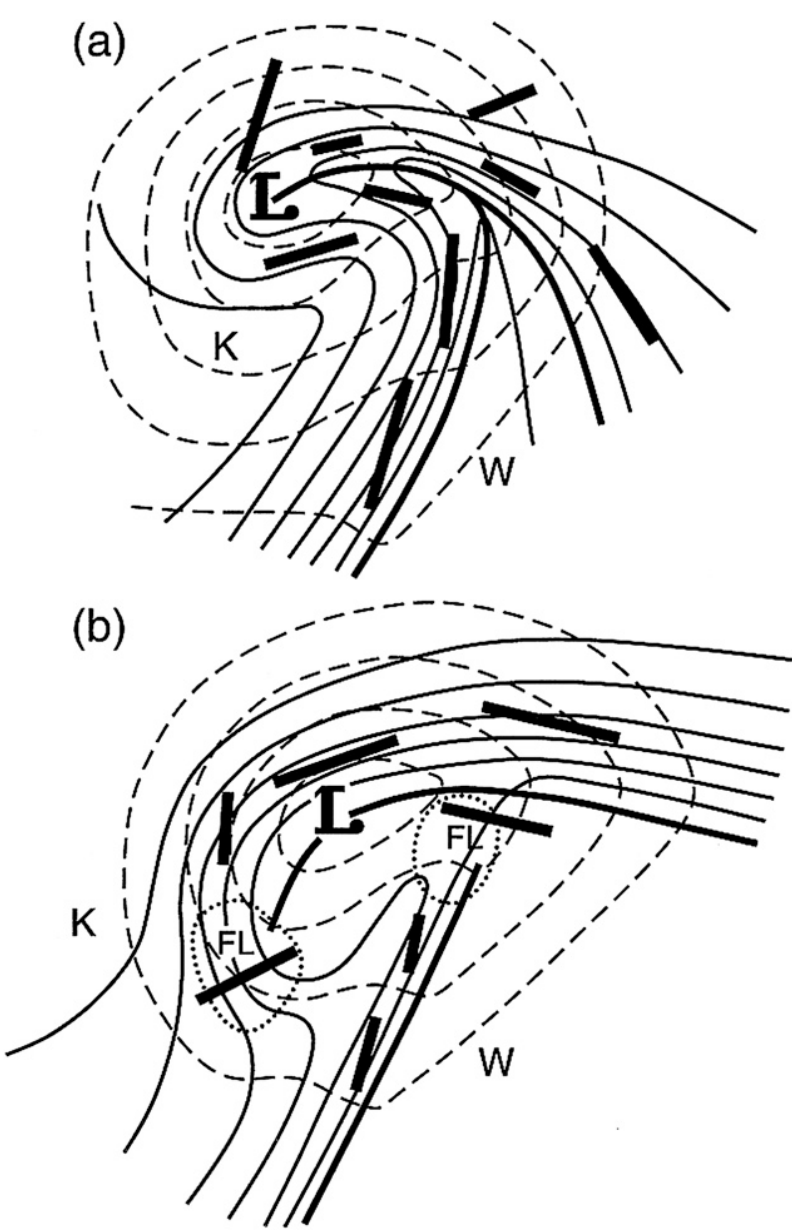

FIG. 7. Schematic comparison of the lower-tropospheric (e.g., $850 \mathrm{hPa}$ ) structures of the (a) Norwegian occlusion and (b) ShapiroKeyser frontal fracture. Dashed lines denote geopotential height, thin solid lines denote potential temperature, thick solid lines represent fronts, and thick line segments represent axes of dilatation of total horizontal wind with segment length proportional to the resultant deformation. Areas surrounded by dotted lines labeled FL in (b) represent regions of frontolysis, and $\mathrm{K}$ and $\mathrm{W}$ in (a) and (b) denote the cold and warm regions of the cyclones, respectively. The characteristic scale of the cyclones based on the distance from the geopotential height minimum, denoted by L, to the outermost geopotential height contour is $1000 \mathrm{~km}$. [Figure and caption from Fig. 10 in Schultz et al. (1998).]

are distinct from the strong winds in the sting jet and are not dealt with in this article. Also, strong winds associated with Norwegian cyclones (cyclones generally lacking strong near-surface frontolysis) would not be diagnosed with this approach.

To summarize, this article showed the value of assessing Petterssen frontogenesis when forecasting the potential for sting jets, thereby elucidating a possible physical mechanism for their initiation: descent due to frontolysis at the end of the bent-back front in ShapiroKeyser cyclones advecting down higher-momentum air toward the surface. Sting jets that reach the surface may be caused by intense frontolysis and strong descent in a weakly stable or unstable environment, encountering near-surface cold advection that further destabilizes the near-surface boundary layer and aids the mixing of momentum. Synthesis of these new results with the previous literature showed that this mechanism is consistent with the previously documented physical characteristics of sting jets. Specifically, frontolysis explains the location of sting jets at the end of the bent-back front, their mesoscale dimensions, and their occurrence within ShapiroKeyser cyclones. The result, therefore, is an improved conceptual model for sting jets as a component of the frontal structure and evolution of Shapiro-Keyser cyclones (Fig. 6). Further cases are necessary to generalize the above results and test the proposed forecast approach.

Acknowledgments. We thank Jim Steenburgh, Geraint Vaughan, Peter Banacos, two anonymous reviewers, and Editor Paul Markowski for their comments on a draft of this manuscript. We especially thank Peter Banacos for suggesting the link between the strong surface winds and the static stability. We also thank Timothy Slater, Sue Gray, David Smart, Keith Browning, Tim Baker, and Peter Knippertz for their discussions. Shea Winterberger performed the simulation, and Deyan Dragov drafted Fig. 6. Partial funding was provided by the U.K. Natural Environment Research Council to the Diabatic Influences on Mesoscale Structures in Extratropical Storms (DIAMET) project at the University of Manchester (Grant NE/I005234/1).

\section{REFERENCES}

Baker, L., 2009: Sting jets in severe northern European wind storms. Weather, 64, 143-148.

— S. L. Gray, and P. A. Clark, 2013a: Idealised simulation of sting-jet cyclones. Quart. J. Roy. Meteor. Soc., doi:10.1002/ qj.2131, in press.

, O. Martínez-Alvarado, J. Methven, and P. Knippertz, 2013b: Flying through extratropical cyclone Friedhelm. Weather, 68, 9-13.

Bennetts, D. A., and B. J. Hoskins, 1979: Conditional symmetric instability-A possible explanation for frontal rainbands. Quart. J. Roy. Meteor. Soc., 105, 945-962.

Bosart, L. F., and S. C. Lin, 1984: A diagnostic analysis of the Presidents' Day storm of February 1979. Mon. Wea. Rev., 112, 2148-2177.

Browning, K. A., 2004: The sting at the end of the tail: Damaging winds associated with extratropical cyclones. Quart. J. Roy. Meteor. Soc., 130, 375-399.

— , and M. Field, 2004: Evidence from Meteosat imagery of the interaction of sting jets with the boundary layer. Meteor. Appl., 11, 277-289.

Cao, Z., 2009: The sting jet in a simulated extratropical cyclone. Open Atmos. Sci. J., 3, 212-218. 
Carlson, T. N., 1980: Airflow through midlatitude cyclones and the comma cloud pattern. Mon. Wea. Rev., 108, 1498-1509.

Chang, S. W., T. R. Holt, and K. D. Sashegyi, 1996: A numerical study of the ERICA IOP 4 marine cyclone. Mon. Wea. Rev., 124, 27-46.

Chelton, D. B., M. H. Freilich, J. M. Sienkiewicz, and J. M. Von Ahn, 2006: On the use of QuikSCAT scatterometer measurements of surface winds for marine weather prediction. Mon. Wea. Rev., 134, 2055-2071.

Chen, F., and J. Dudhia, 2001: Coupling an advanced land surfacehydrology model with the Penn State-NCAR MM5 modeling system. Part I: Model description and implementation. Mon. Wea. Rev., 129, 569-585.

Chen, S.-H., and W.-Y. Sun, 2002: A one-dimensional time dependent cloud model. J. Meteor. Soc. Japan, 80, 99-118.

Clark, P. A., K. A. Browning, and C. Wang, 2005: The sting at the end of the tail: Model diagnostics of fine-scale three-dimensional structure of the cloud head. Quart. J. Roy. Meteor. Soc., 131, 2263-2292.

Crescenti, G. H., and R. A. Weller, 1992: Analysis of surface fluxes in the marine atmospheric boundary layer in the vicinity of rapidly intensifying cyclones. J. Appl. Meteor., 31, 831-848.

desJardins, M. L., K. F. Brill, and S. S. Schotz, 1991: Use of GEMPAK on UNIX workstations. Proc. Seventh Int. Conf. on Interactive Information and Processing Systems for Meteorology, Oceanography, and Hydrology, New Orleans, LA, Amer. Meteor. Soc., 449-453.

Eliassen, A., 1962: On the vertical circulation in frontal zones. Geofys. Publ., 24, 147-160.

Fox, A., R. Sherwin, and F. Ralston, 2012: Lessons learnt at the Met Office from the Great Storm of 1987-A comparison with recent strong wind events. Weather, 67, 268-273.

Galarneau, T. J., L. F. Bosart, and R. S. Schumacher, 2010: Predecessor rain events ahead of tropical cyclones. Mon. Wea. Rev., 138, 3272-3297.

Gozzo, L. F., and R. P. da Rocha, 2013: Air-sea interaction processes influencing the development of a Shapiro-Keyser type cyclone over the subtropical South Atlantic Ocean. Pure Appl. Geophys., 170, 917-934, doi:10.1007/s00024-012-0584-3.

Gray, S. L., O. Martínez-Alvarado, L. H. Baker, and P. A. Clark, 2011: Conditional symmetric instability in sting-jet storms. Quart. J. Roy. Meteor. Soc., 137, 1482-1500.

Grønås, S., 1995: The seclusion intensification of the New Year's Day storm 1992. Tellus, 47A, 733-746.

Hanafin, J. A., and Coauthors, 2012: Phenomenal sea states and swell from a North Atlantic storm in February 2011. Bull. Amer. Meteor. Soc., 93, 1825-1832.

Harr, P. A., and R. L. Elsberry, 2000: Extratropical transition of tropical cyclones over the western North Pacific. Part I: Evolution of structural characteristics during the transition process. Mon. Wea. Rev., 128, 2613-2633.

Hoffman, R. N., and S. M. Leidner, 2005: An introduction to the near-real-time QuikSCAT data. Wea. Forecasting, 20, 476-493.

Hong, S.-Y., Y. Noh, and J. Dudhia, 2006: A new vertical diffusion package with an explicit treatment of entrainment processes. Mon. Wea. Rev., 134, 2318-2341.

Kain, J. S., 2004: The Kain-Fritsch convective parameterization: An update. J. Appl. Meteor., 43, 170-181.

—, and J. M. Fritsch, 1990: A one-dimensional entraining/ detraining plume model and its application in convective parameterization. J. Atmos. Sci., 47, 2784-2802.

_ and _ 1993: Convective parameterization for mesoscale models: The Kain-Fritsch scheme. The Representation of
Cumulus Convection in Numerical Models, Meteor. Monogr., No. 46, Amer. Meteor. Soc., 165-170.

Keshishian, L. G., and L. F. Bosart, 1987: A case study of extended East Coast frontogenesis. Mon. Wea. Rev., 115, 100-117.

,$- \ldots$, and W. E. Bracken, 1994: Inverted troughs and cyclogenesis over interior North America: A limited regional climatology and case studies. Mon. Wea. Rev., 122, 565-607.

Keyser, D., and M. J. Pecnick, 1985: A two-dimensional primitive equation model of frontogenesis forced by confluence and horizontal shear. J. Atmos. Sci., 42, 1259-1282.

— M. J. Reeder, and R. J. Reed, 1988: A generalization of Petterssen's frontogenesis function and its relation to the forcing of vertical motion. Mon. Wea. Rev., 116, 762-780.

Knox, J. A., J. D. Frye, J. D. Durkee, and C. M. Fuhrmann, 2011: Non-convective high winds associated with extratropical cyclones. Geogr. Compass, 5, 63-89.

Koch, S. E., 1984: The role of an apparent mesoscale frontogenetic circulation in squall line initiation. Mon. Wea. Rev., 112, 20902111.

Lackmann, G., 2011: Midlatitude Synoptic Meteorology: Dynamics, Analysis and Forecasting. Amer. Meteor. Soc., 345 pp.

Lin, Y.-L., R. D. Farley, and H. D. Orville, 1983: Bulk parameterization of the snow field in a cloud model. J. Climate Appl. Meteor., 22, 1065-1092.

Lynott, R. E., and O. P. Cramer, 1966: Detailed analysis of the 1962 Columbus Day windstorm in Oregon and Washington. Mon. Wea. Rev., 94, 105-117.

Market, P. S., and J. T. Moore, 1998: Mesoscale evolution of a continental occluded cyclone. Mon. Wea. Rev., 126, 1793 1811.

Martin, J. E., 1998a: The structure and evolution of a continental winter cyclone. Part I: Frontal structure and the occlusion process. Mon. Wea. Rev., 126, 303-328.

_ 1998b: The structure and evolution of a continental winter cyclone. Part II: Frontal forcing of an extreme snow event. Mon. Wea. Rev., 126, 329-348.

Martínez-Alvarado, O., S. L. Gray, P. A. Clark, and L. H. Baker, 2011: Objective detection of sting jets in low-resolution datasets. Meteor. Appl., 17, 340-354.

,-- J. L. Catto, and P. A. Clark, 2012: Sting jets in intense winter North-Atlantic windstorms. Environ. Res. Lett., 7, 024014.

Mass, C., and B. Dotson, 2010: Major extratropical cyclones of the northwest United States: Historical review, climatology, and synoptic environment. Mon. Wea. Rev., 138, 2499-2527.

Mlawer, E. J., S. J. Taubman, P. D. Brown, M. J. Iacono, and S. A. Clough, 1997: Radiative transfer for inhomogeneous atmospheres: RRTM, a validated correlated $k$ model for the longwave. J. Geophys. Res., 102 (D14), 16 663-16682.

Moore, B. J., L. F. Bosart, D. Keyser, and M. L. Jurewicz, 2013: Synoptic-scale environments of predecessor rain events occurring east of the Rocky Mountains in association with Atlantic basin tropical cyclones. Mon. Wea. Rev., 141, 1022-1047.

Neiman, P. J., M. A. Shapiro, E. G. Donall, and C. W. Kreitzberg, 1990: Diabatic modification of an extratropical marine cyclone warm sector by cold underlying water. Mon. Wea. Rev., 118, 1576-1590.

—, _ and L. S. Fedor, 1993: The life cycle of an extratropical marine cyclone. Part II: Mesoscale structure and diagnostics. Mon. Wea. Rev., 121, 2177-2199.

Nielsen, N. W., and B. H. Sass, 2003: A numerical, high-resolution study of the life cycle of the severe storm over Denmark on 3 December 1999. Tellus, 55A, 338-351. 
Novak, D. R., L. F. Bosart, D. Keyser, and J. S. Waldstreicher, 2004: An observational study of cold season-banded precipitation in northeast U.S. cyclones. Wea. Forecasting, 19, 993-1010.

— J. J. Waldstreicher, D. Keyser, and L. F. Bosart, 2006: A forecast strategy for anticipating cold season mesoscale band formation within eastern U.S. cyclones. Wea. Forecasting, 21, $3-23$.

— B. A. Colle, and S. E. Yuter, 2008: High-resolution observations and model simulations of the life cycle of an intense mesoscale snowband over the northeastern United States. Mon. Wea. Rev., 136, 1433-1456.

- - - , and R. McTaggart-Cowan, 2009: The role of moist processes in the formation and evolution of mesoscale snowbands within the comma head of northeast U.S. cyclones. Mon. Wea. Rev., 137, 2662-2686.

—_ — - and A. R. Aiyyer, 2010: Evolution of mesoscale precipitation band environments within the comma head of northeast U.S. cyclones. Mon. Wea. Rev., 138, 23542374.

Parton, G. A., G. Vaughan, E. G. Norton, K. A. Browning, and P. A. Clark, 2009: Wind profiler observations of a sting jet. Quart. J. Roy. Meteor. Soc., 135, 663-680.

—, A. Dore, and G. Vaughan, 2010: A climatology of midtropospheric mesoscale strong wind events as observed by the MST radar, Aberystwyth. Meteor. Appl., 17, 340-354.

Petterssen, S., 1936: Contribution to the theory of frontogenesis. Geofys. Publ., 11 (6), 1-27.

Roebber, P. J., J. R. Gyakum, and D. N. Trat, 1994: Coastal frontogenesis and precipitation during ERICA IOP 2. Wea. Forecasting, 9, 21-44.

Rotunno, R., W. C. Skamarock, and C. Snyder, 1998: Effects of surface drag on fronts within numerically simulated baroclinic waves. J. Atmos. Sci., 55, 2119-2129.

Rutledge, S. A., and P. V. Hobbs, 1984: The mesoscale and microscale structure and organization of clouds and precipitation in midlatitude cyclones. XII: A diagnostic modeling study of precipitation development in narrow cold-frontal rainbands. J. Atmos. Sci., 41, 2949-2972.

Sanders, F., 2000: Frontal focusing of a flooding rainstorm. Mon. Wea. Rev., 128, 4155-4159.

Satyamurty, P., and L. F. De Mattos, 1989: Climatological lower tropospheric frontogenesis in the midlatitudes due to horizontal deformation and divergence. Mon. Wea. Rev., 117, 1355-1364.

Schär, C., and H. Wernli, 1993: Structure and evolution of an isolated semi-geostrophic cyclone. Quart. J. Roy. Meteor. Soc., 119, 57-90.

Schultz, D. M., 2001: Reexamining the cold conveyor belt. Mon. Wea. Rev., 129, 2205-2225.

- 2004: Cold fronts with and without prefrontal wind shifts in the central United States. Mon. Wea. Rev., 132, 2040-2053.

— cyclone over land. Mon. Wea. Rev., 121, 918-940.

— tional symmetric instability. Mon. Wea. Rev., 127, 2709-2732; Corrigendum, 128, 1573.
— , and J. A. Knox, 2007: Banded convection caused by frontogenesis in a conditionally, symmetrically, and inertially unstable environment. Mon. Wea. Rev., 135, 2095-2110.

_ , and F. Zhang, 2007: Baroclinic development within zonallyvarying flows. Quart. J. Roy. Meteor. Soc., 133, 1101-1112.

- and G. Vaughan, 2011: Occluded fronts and the occlusion process: A fresh look at conventional wisdom. Bull. Amer. Meteor. Soc., 92, 443-466, ES19-ES20.

— D. Keyser, and L. F. Bosart, 1998: The effect of large-scale flow on low-level frontal structure and evolution in midlatitude cyclones. Mon. Wea. Rev., 126, 1767-1791.

Schumacher, R. S., D. M. Schultz, and J. A. Knox, 2010: Convective snowbands downstream of the Rocky Mountains in an environment with conditional, dry symmetric, and inertial instabilities. Mon. Wea. Rev., 138, 4416-4438.

Shapiro, M. A., and D. Keyser, 1990: Fronts, jet streams and the tropopause. Extratropical Cyclones, The Erik Palmén Memorial Volume, C. W. Newton and E. O. Holopainen, Eds., Amer. Meteor. Soc., 167-191.

Skamarock, W. C., J. B. Klemp, J. Dudhia, D. O. Gill, D. M. Barker, W. Wang, and J. G. Powers, 2005: A description of the Advanced Research WRF version 2. NCAR Tech. Note NCAR/TN-468+STR, 100 pp. [Available online at http:// wrf-model.org/wrfadmin/docs/arw_v2.pdf.]

Smart, D. J., and K. A. Browning, 2013: Attribution of strong winds to a cold conveyor belt and sting jet. Quart. J. Roy. Meteor. Soc., doi:10.1002/qj.2162, in press.

Steenburgh, W. J., and C. F. Mass, 1994: The structure and evolution of a simulated Rocky Mountain lee trough. Mon. Wea. Rev., 122, 2740-2761.

$\longrightarrow$, and - 1996: Interaction of an intense extratropical cyclone with coastal orography. Mon. Wea. Rev., 124,1329-1352.

— C. C. R. Neuman, G. L. West, and L. F. Bosart, 2009: Discrete frontal propagation over the Sierra-Cascade Mountains and Intermountain West. Mon. Wea. Rev., 137, 2000-2020.

Takayabu, I., 1986: Roles of the horizontal advection on the formation of surface fronts and on the occlusion of a cyclone developing in the baroclinic westerly jet. J. Meteor. Soc. Japan, 64, 329-345.

Tao, W.-K., J. Simpson, and M. McCumber, 1989: An ice-water saturation adjustment. Mon. Wea. Rev., 117, 231-235.

Thorpe, A. J., and K. A. Emanuel, 1985: Frontogenesis in the presence of small stability to slantwise convection. J. Atmos. Sci., 42, 1809-1824.

Trapp, R. J., D. M. Schultz, A. V. Ryzhkov, and R. L. Holle, 2001: Multiscale structure and evolution of an Oklahoma winter precipitation event. Mon. Wea. Rev., 129, 486-501.

Von Ahn, J., J. Sienkiewicz, and G. McFadden, 2005: Hurricane force extratropical cyclones observed using QuikSCAT near real time winds. Mar. Wea. Log, 49 (1). [Available online at http://www.vos.noaa.gov/MWL/april_05/cyclones.shtml.]

,,- , and P. S. Chang, 2006: Operational impact of QuikSCAT winds at the NOAA Ocean Prediction Center. Wea. Forecasting, 21, 523-539.

West, G. L., and W. J. Steenburgh, 2010: Life cycle and mesoscale frontal structure of an intermountain cyclone. Mon. Wea. Rev., 138, 2528-2545. 